\title{
Are Migration Policies that InduCE SKILLED (UNSKILLED) MigRATION BENEFICIAL (HARMFUL) FOR THE HOST COUNTRY?
}

\author{
MiCHAEL S. MICHAEL \\ CESIFO WORKING PAPER NO. 1814 \\ CATEgORY 7: TRAdE POLICY \\ SEPTEMBER 2006
}

An electronic version of the paper may be downloaded

- from the SSRN website:

- from the RePEc website:

wWw.SSRN.com

- from the CESifo website:

www.RePEc.org

www.CESifo-group.de 


\title{
ARe Migration Policies THAT IndUCE SKILLED (UNSKILLED) MigRATION BENEFICIAL (HARMFUL) FOR THE HOST COUNTRY?
}

\begin{abstract}
This paper investigates the welfare consequences of immigration policies in a model with two types of labour, skilled and unskilled, and international capital mobility. The paper examines the effect of government policies - which change the immigration cost and causes immigration of one type of labour - on the welfare of natives when the other type of labour and/or capital are also mobile. It is shown that in the absence of capital mobility, if skilled and unskilled labour are highly complementary in production (as attested by many empirical studies), then a decrease in the immigration cost of the net fiscal contributor skilled labour decreases the welfare of natives.
\end{abstract}

JEL Code: F22, H24.

Keywords: migration policies, skilled and unskilled labour, capital mobility, welfare.

\author{
Michael S. Michael \\ Department of Economics \\ University of Cyprus \\ PO Box 20537 \\ Nicosia, CY 1678 \\ Cyprus \\ m.s.michael@ucy.ac.cy
}

September 2006

The author is grateful to Panos Hatzipanayotou and Costas Hadjiyiannis for details, comments and suggestions. 


\section{Introduction}

The large differences in wages between Developed and Developing Countries cause a strong desire for migration towards the high wage Developed Countries. Developed Countries, however, are less willing to accept mass migration, even though the traditional international migration theory predicts that in most cases immigration is beneficial for the natives of the host country. ${ }^{1}$ Most Developed Countries accept only a small percentage of prospective migrants from Developing Countries. This restrictive immigration policy is not only due to the effect of immigration on local labour market and wages but also due to the fiscal effects of immigration. In modern economies, governments impose income and other taxes and implement programs which transfer income in cash or in kind such as education, health etc. It is argued that immigrants are net fiscal beneficiaries in the sense that their contributions through taxes fall short of the direct or indirect benefits they enjoy from such government provisions. Wildasin (2004), for example, found that in Germany, Sweden and Demark where the immigrants are around 10 percent of the total population, that they are recipients of over 30 percent of the total cash welfare expenditures.

In the last two decades, there is a growing interest in the literature on the welfare effects of migration in economies that impose taxes and make income transfers and provide public goods. ${ }^{2}$ For example, Wildasin (1994) using a single good model with income taxes and transfers shows that free immigration may lead to Pareto- inferior outcomes if in the no-immigration situation owners of the immobile factor are being taxed to provide transfer payments to mobile workers. Michael (2003), in a model with income taxes and transfers, many factors of production and many traded and non-traded goods has shown that marginal immigration hurts the natives when labour is homogeneous. ${ }^{3}$

In recent years the immigration policies of the Developed Countries are designed in such a way so that immigration is easier for the skilled rather than the unskilled workers. For example, Carrington and Detragiache (1998) using data for

\footnotetext{
${ }^{1}$ It has been shown that in the absence of income taxes, transfers and public goods, finite permanent migration is beneficial for the nationals in the host country and detrimental for people left behind in the source country and that marginal migration has no welfare effects in either country (e.g., Berry and Soligo 1969, Wong 1985 and Quibria 1988).

${ }^{2}$ Michael and Hatzipanayotou (2001) have examined the welfare effects of migration in a model where revenue from indirect taxes are used to finance the provision of public goods.

${ }^{3}$ Income taxes and transfers in migration models have also been used among others by Huizinga (1999), Bucovetsky (2003) and Epstein and Hillman (2003).
} 
OECD countries find that individuals with little or no education generally have limited access to international migration mainly due to institutional barriers. It is argued that this is due to the fact that skilled immigrants are expected to be net fiscal contributors and thus their immigration is beneficial for the natives. ${ }^{4,5}$ This is in line with the finding of Wellisch and Wildasin (1996) where in a model with constant goods prices and many jurisdictions have shown that immigration raises welfare in jurisdictions where immigrants are net fiscal contributors and it lowers welfare in jurisdictions where they are net fiscal beneficiaries. $^{6}$

The purpose of this paper is to extend the previous results and to try to explain the phenomenon whereby in many European countries although the immigration policies are designed to facilitate the immigration of the skilled, fiscal contributors workers, at the end, the majority of immigrants are net fiscal beneficiaries unskilled workers. To achieve this, we build a model where we have two types of workers, skilled with more education and high ability and productivity and unskilled with less education and low ability and productivity. The government imposes the same income tax rate on all incomes and the tax receipts are equally distributed to all residents. Within this framework and under different scenarios regarding the international mobility of skilled, unskilled workers and capital we examine the effects on the welfare of natives of changes in immigration policies which change the immigration cost and induce or discourage immigration. Governments can change the immigration cost using either taxes and or other indirect ways which can impede or facilitate immigration by making it less or more risky, and less or more expensive. This model can describe, for example, the situation in the countries of the European Union, where there are free movements of labour and capital between them, and each country can take measures to encourage or discourage immigration of certain types of labour from non European Union countries (e.g., to encourage the immigration of

\footnotetext{
${ }^{4}$ Another reason for the less restrictive immigration policy for high-skilled workers is the shortage of high-skilled workers in many developed countries. See for example Bauer and Kunze (2004).

${ }^{5}$ Bellettini and Ceroni (2003) assuming that migration rate is higher among highly educated workers show that the optimal immigration policy from the point of view of natives is an immigration quota above a certain minimum level.

${ }^{6}$ Razin and Sadka (2004), in an infinite-horizon, overlapping generations economy, show that this net burden due to immigration of the low-skilled labour could change to net gain to the native-born population.
} 
skilled labour). ${ }^{7}$ We identify the conditions under which government policies which change the immigration cost can improve or deteriorate the welfare of natives. For example, it is shown that, in the absence of capital mobility, if skilled and unskilled labour is complements in production, as many empirical studies attest to a high degree of complementarities between the two factors, then a decrease in the immigration cost of skilled labour, which causes inflow of net fiscal contributor skilled labour, decreases the welfare of natives.

\section{The Model}

Consider a small open country, Home, that trades freely with the rest of the world. In Home there are two types of workers, skilled and unskilled. Skilled workers are more educated, have more abilities and thus are more productive. There are three types of agents, those possessing only one unit of unskilled labour, those possessing only one unit of skilled labour and finally those possessing one unit of capital. Migration is assumed to take place only from the group of agents possessing only a unit of either skilled or unskilled labour. Moreover, migration is assumed to be permanent in the sense that immigrants do not remit any of their income earnings in the host country to the source country. We denote with $\mathrm{L}$ the number of agents that posses only unskilled labour, with $\mathrm{H}$ the number of agents that posses only skilled labour and with $\mathrm{F}$ the number of agents that posses only capital.

Let $e^{j}\left(u^{j}\right)$ be the minimum expenditure of an individual belonging to group $\mathrm{j}(\mathrm{j}=\mathrm{L}, \mathrm{H}, \mathrm{F})$ required to achieve a level of utility $\mathrm{u}$ given the fixed world prices of goods. The country produces many traded goods using skilled and unskilled labour, and capital (i.e., K). With $\mathrm{R}(\mathrm{L}, \mathrm{H}, \mathrm{K})$ we denote the maximum value of the Gross Domestic Product (GDP) given the goods prices and the domestic supply of factors of production. The fixed prices of the traded goods are omitted from the GDP function since they do not affect the analysis. The partial derivatives of the R(H,K,L) function with respect to $L, H$, and $K$ (i.e., $R_{L}, R_{H}$, and $R_{K}$ ) give the marginal revenue products of unskilled, skilled workers and capital, respectively. Our assumption that skilled workers are more productive than the unskilled ones implies that $R_{H}>R_{L}$. The

\footnotetext{
${ }^{7}$ The analysis is also applicable to non EU countries. For example, USA relaxes its immigration policies on skilled workers which cause their inflow. The inflow of skilled workers increases the wages of unskilled workers which somehow, legally or illegally, make their way into USA.
} 
GDP function is assumed strictly concave in both types of labour and capital (e.g., $\mathrm{R}_{\mathrm{LL}}<0$ ) and homogenous of degree one in all factors. ${ }^{8}$

Capital is perfectly mobile internationally and Home is a small country in the world capital markets. Equilibrium in the Home capital market requires that

$$
r^{*}=(1-\rho) R_{K}(L, H, K)
$$

where $\mathrm{r}^{*}$ is the world net rate of return to capital and $\rho$ is the Home linear income tax rate and is the same for all income from all factors of production and it is assumed fixed. ${ }^{9}$ Income tax revenue is equally distributed to all residents in the country. ${ }^{10}$ That is, each agent in the country receives a transfer payment $T=\rho R(H, L, K) / N$, where $\mathrm{N}=\mathrm{L}+\mathrm{H}+\mathrm{F}$, is the total number of residents (agents) in the country. ${ }^{11}$ Since $\rho$ is fixed, $\mathrm{T}$ is adjusted to satisfy the budget constraint when migration occurs.

The country's income expenditure identity requires that expenditure by all residents must equal to total net income from production plus transfer payments, minus net payments to foreign capital. ${ }^{12}$ That is

$$
L e^{L}\left(u^{L}\right)+H e^{H}\left(u^{H}\right)+F e^{F}\left(u^{F}\right)=R(L, H, K)-r^{*} K^{f},
$$

where $\mathrm{K}^{\mathrm{f}}$ is positive (negative) if the Home is a net capital importer (exporter).

It is assumed that an immigrant receives as a wage his marginal revenue product of its labour. Thus, a skilled or an unskilled worker migrates if in the host country his net income from labour plus the transfer payments minus the migration cost is higher than the net income he receives in the source country and migration

\footnotetext{
${ }^{8}$ This assumption implies that $R_{j j}<0$ and $R_{j j} R_{i i}-R_{i j}^{2}>0$ for $\mathrm{i}, \mathrm{j}=\mathrm{L}, \mathrm{K}, \mathrm{H}$. Note that when the number of traded goods equal the number of factors of production, the above assumption does not hold. ${ }^{9}$ See Razin and Sadka (1995) for the use of a linear income tax rate in a similar analysis.

${ }^{10}$ Razin, Sadka and Swagel (2002), in a political economy model, link the rate of low-skill immigration with the tax burden and redistribution. Using data on 11 European countries, they found that higher share of low-education immigrants in the population leads to a lower tax rate on labour income and less generous transfers.

${ }^{11}$ It is assumed that the redistributive fiscal policy is fixed and that the new immigrants cannot be excluded from the benefits and costs of this policy. That is, the country treads all individuals equally regardless of their origin. For an extensive discussion of this issue, see for example Wellisch and Wildasin (1996).

12 The analysis of this paper considers changes in policies which cause marginal migration.
} 
stops when the two are equal. Thus equilibrium in the $\mathrm{j}^{\text {th }}$ labour market is achieved when

$$
w^{* j}=(1-\rho) R_{j}(L, H, K)+T-t_{j},
$$

where $w^{* j}$ is the net income of a worker that belongs to group $j(j=L, H)$ receives in the source country and $t_{j}$ is the migration cost of a worker that belongs in group $j$. The migration cost can include taxes, moving cost, settlement cost etc. It is assumed that the host country is small in the world factor markets and thus the inflow of foreign workers does not affect their net income they receive in the source countries.

The expenditure of a worker that belongs in group $\mathrm{j}$ equals his net wage income, plus the transfer payments he receives and is given by

$$
e^{j}=(1-\rho) R_{j}+T
$$

The social welfare function is defined as the weighed sum of utilities of all agents in the country with constant number of individuals. Differentiating equation (2) and using equations (1), (3) and (4), we get

$$
d W=-\rho \lambda_{L} d L-\rho \lambda_{H} d H+\rho R_{K} d K
$$

where $d W=L e_{u}^{L} d u^{L}+H e_{u}^{H} d u^{H}+F e_{u}^{F} d u^{F}$ is the weighted sum of changes in the utility of all the initial residents in the host country. ${ }^{13}$ We call $\mathrm{dW}$ the change in social welfare or the change in the welfare of natives. Also, using equation (4), we defined $\lambda_{j}=\left(R-N R_{j}\right) / N$. For the unskilled labour $\lambda_{L}=\left(R-N R_{L}\right) / N$ is positive since it is assumed that its marginal revenue product is lower than that of the skilled labour. In other words, $\lambda_{L}\left(=(R / N)-R_{L}\right)=\bar{R}-R_{L}$, where $\bar{R}=R / N$, is positive since the average income is greater than the marginal revenue product of the unskilled labour. Intuitively, an unskilled worker receives $\rho R / N$ transfer payments and pays $\rho R_{L}$ taxes. Since the former exceeds the latter, the unskilled worker is a net fiscal

\footnotetext{
${ }^{13}$ Since the prices of goods are fixed, changes in the utilities of individuals are perfect measures of changes in incomes.
} 
beneficiary. For the skilled labour, however, $\lambda_{H}\left(=\left(R-N R_{H}\right) / N\right)=\bar{R}-R_{H}$ can be either positive or negative. In the case where only skilled and unskilled labour exists, that is, no other factors exist, then $\lambda_{H}$ is unambiguously negative. For the analysis that follows, it is assumed that $\lambda_{H}$ is negative. The assumption that $\lambda_{H}$ is negative implies that the marginal revenue product of the skilled labour is greater than the average income and that the skilled workers are net fiscal contributors. That is, the tax payments of a skilled worker $\rho R_{H}$ exceed the transfer payments he receives $\rho R / N$. Let us also define $\lambda_{K}=\bar{R}-R_{K}$. We assume that a capitalist is also net fiscal contributor and thus $\lambda_{K}$ is negative. Equation (5) shows that an inflow (outflow) of unskilled workers reduces (increases) the social welfare of the country if the domestic supply of the other factors remain fixed. The opposite, however, is true for the skilled workers. An inflow (outflow) of skilled workers increases (decreases) social welfare.

Differentiating equation (1) and (3) gives

$$
\begin{aligned}
& (1-\rho)\left(R_{K K} d K+R_{K L} d L+R_{K H} d H\right)=0, \\
& N d w^{* j}=\left[(1-\rho) N R_{j H}-\rho \lambda_{H}\right] d H+\left[(1-\rho) N R_{j L}-\rho \lambda_{L}\right] d L \\
& +\left[(1-\rho) N R_{j K}+\rho R_{K}\right] d K-N d t_{j}=0 .
\end{aligned}
$$

\section{Migration with internationally immobility of capital}

In this section, for simplicity, it is assumed that capital is internationally immobile and that foreign owned capital does not exists in the country. That is, Home economic policies do not induce any international movements of capital, and thus the stock of the capital in the country remains fixed. Under this assumption we examine two cases. In case one, the international mobility of unskilled workers is free while the mobility of skilled workers is restricted. In the second case, the opposite scenario is considered. ${ }^{14}$

\footnotetext{
${ }^{14}$ The analysis of this paper, as we have mentioned before, considers changes in policies which cause marginal immigration. In the case where we have finite immigration and the immigrants receive as a wage, the marginal revenue product of the last immigrant, then in this case there is an extra, positive effect, on the welfare of natives.
} 


\subsection{International mobility of unskilled workers}

First, it is assumed that unskilled workers are freely mobile internationally but the international mobility of skilled workers is restricted. Using equation (5) and equation (7) for the case where $\mathrm{j}=\mathrm{L}$, and noting that $\mathrm{dH}=0$, we get the effect of a change in the immigration cost of unskilled workers as follows:

$$
\Delta_{L}\left(d W / d t_{L}\right)=-\rho N \lambda_{L},
$$

where $\Delta_{L}=(1-\rho) N R_{L L}-\rho \lambda_{L}$ and is negative. From equation (8) it is clear that an increase in the immigration cost of unskilled workers, who are net fiscal beneficiaries, reduces their immigration and raises the host country's social welfare. ${ }^{15}$

Next, we examine how exogenous immigration of skilled workers affects social welfare in the presence of free international mobility of unskilled workers. Using equations (5) and (7) we get

$$
\Delta_{L}(d W / d H)=\rho(1-\rho) N R_{L L}\left(-\lambda_{H}+\lambda_{L} R_{L L}^{-1} R_{L H}\right) .
$$

Equation (9) shows that an exogenous inflow of skilled workers increases social welfare if skilled and unskilled workers are substitutes in production (i.e., $\mathrm{R}_{\mathrm{LH}}<0$ ). ${ }^{16}$ Intuitively, the immigration of skilled workers increases welfare directly since they are net fiscal contributors and indirectly by reducing the immigration of the unskilled workers who are net fiscal beneficiaries. If, however, skilled and unskilled workers are complements in production (i.e., $\mathrm{R}_{\mathrm{LH}}>0$ ), then the immigration of skilled workers causes also immigration of unskilled workers making the total welfare effect of an exogenous immigration of skilled labour ambiguous. To derive more precise results, we rewrite (9) as follows:

$$
\Delta_{L}(d W / d H)=\rho(1-\rho)(N / H) R_{L L}\left[F \lambda_{K}+L \lambda_{L}\left(\varepsilon_{L L}+\varepsilon_{L H}\right) / \varepsilon_{L L}\right]
$$

\footnotetext{
${ }^{15}$ As noted in the introduction, the government can change the immigration cost by using either taxes on labour movements, or by other indirect ways which could make immigration easier or harder and more or less expensive.

${ }^{16}$ In the theory of production if $\mathrm{R}_{\mathrm{LH}}>0(<0)$, then the two factors are q-complements (q-substitutes). In this paper when we say complements (substitutes) in production we mean q-complements (qsubstitutes). In the case where only two factors exist, with constant returns to scale production function, then the two factors are always q-complements in production (e.g., $\mathrm{R}_{\mathrm{LH}}>0$ ), and p-substitutes.
} 
where $\varepsilon_{L L}=\left(\partial R_{L} / \partial L\right)\left(L / R_{L}\right) \prec 0, \quad \varepsilon_{L H}=\left(\partial R_{L} / \partial H\right)\left(H / R_{L}\right), \quad \lambda_{K}=\bar{R}-R_{K}<0$, and we make used of the fact that $L \lambda_{L}+H \lambda_{H}+F \lambda_{K}=K^{f} R_{K}$. Note that in this section we assume that there is no foreign capital in the country $\left(K^{f}=0\right)$. From equation (10) we see that if skilled and unskilled labour are complements in production and the elasticity of the wage rate of the unskilled labour with respect to skilled labour is greater than the absolute value of the elasticity of the wage rate of the unskilled labour with respect to unskilled labour (i.e., $\varepsilon_{L H}>-\varepsilon_{L L}$ ) (sufficient but not necessary condition) then the inflow of the skilled labour unambiguously decreases social welfare. Intuitively, when skilled and unskilled workers are complements in production and the elasticity is high, the inflow of skilled workers increases a lot the wage rate for the unskilled ones which causes a large inflow of them. Thus, even though the inflow of skilled workers has a positive effect on the welfare of natives, the resulting large inflow of unskilled workers has a negative effect, which dominates the positive one and causes the welfare of natives to decrease. Most of the studies surveyed by Hamermesh (1993, p.110) found that blue collar workers are complements in production with white collar workers and the elasticities of substitution between blue and white collar workers are higher than the absolute value of the own demand elasticity of the blue collar workers. We can consider the blue collar workers as the unskilled workers and the white collar workers as the skilled workers. Based on the results of the above studies we can conclude that the inflow of the skilled workers decreases social welfare. ${ }^{17}$

\subsection{International mobility of skilled workers}

Next, it is assumed that there is international mobility of skilled workers, while the international mobility of unskilled workers is restricted. Within this framework, we examine how changes in the immigration cost of the skilled workers and how an exogenous inflow of unskilled workers affects social welfare. Using equation (5) and equation (7) for the case where $\mathrm{j}=\mathrm{H}$, gives

\footnotetext{
${ }^{17}$ For example, Germany increases the immigration of high skilled net fiscal contributors' computer scientists from India. This causes the immigration of unskilled net fiscal beneficiary workers from Poland which decreases the welfare of natives in Germany.
} 


$$
\Delta_{H}\left(d W / d t_{H}\right)=-\rho N \lambda_{H},
$$

where $\Delta_{H}=(1-\rho) N R_{H H}-\rho \lambda_{H}$ and is negative. ${ }^{18}$ Equation (11) shows that a decrease in the immigration cost of skilled workers increases social welfare. Intuitively, the decrease in the immigration cost causes domestic supply of skilled workers to increase and since they are net fiscal contributors social welfare increases.

The effect of an exogenous immigration of unskilled workers, e.g., due to a relaxation of immigration restrictions, on social welfare is given by

$$
\Delta_{H}(d W / d L)=\rho(1-\rho) N R_{H H}\left[-\lambda_{L}+\lambda_{H} R_{H H}^{-1} R_{H L}\right]
$$

Equation (12) shows that an exogenous immigration of unskilled workers decreases social welfare if skilled and unskilled workers are substitutes in production (i.e., $\mathrm{R}_{\mathrm{HL}}<0$ ). Intuitively, when an unskilled worker immigrates, social welfare decreases directly since he is a net fiscal beneficiary and indirectly by reducing the immigration of skilled workers who are net fiscal contributors. If, however, skilled and unskilled workers are complements in production, then the immigration of unskilled workers causes immigration of skilled workers and the indirect effect on welfare is positive, making the total effect on welfare ambiguous.

To make things more clear lets rewrite equation (12) as

$$
\Delta_{H}(d W / d L)=\rho(1-\rho)(N / L) R_{H H}\left[F \lambda_{K}+H \lambda_{H}\left(\varepsilon_{H H}+\varepsilon_{H L}\right) / \varepsilon_{H H}\right] .
$$

where $\varepsilon_{H H}=\left(\partial R_{H} / \partial H\right)\left(H / R_{H}\right) \prec 0, \quad \varepsilon_{H L}=\left(\partial R_{H} / \partial L\right)\left(L / R_{H}\right), \quad \lambda_{K}=\bar{R}-R_{K}<0$, and we make used of the fact that $L \lambda_{L}+H \lambda_{H}+F \lambda_{K}=K^{f} R_{K}$. Note that in this section we assume that $K^{f}=0$. From equation (13) we see that if skilled and unskilled labour are complements in production and the elasticity of the wage rate of the skilled labour with respect to unskilled labour is greater than the absolute value of the elasticity of

\footnotetext{
${ }^{18}$ The sign of $\Delta_{H}$ is not clear that is negative. Using equations (5) and (7) when $\mathrm{dL}=0$, and considering welfare and the net income of the skilled workers as the endogenous variable we get that $\left(d w^{* H} / d H\right)=\Delta_{H}$. It is assumed that an increase in the domestic supply of skilled workers decreases the net income of a skilled worker, which implies that $\Delta_{H}$ is negative.
} 
the wage rate of the skilled labour with respect to skilled labour (i.e., $\varepsilon_{H L}>-\varepsilon_{H H}$ ) (necessary but not sufficient), then the inflow of the unskilled labour may increase social welfare. For example, if $\varepsilon_{H L}=-2 \varepsilon_{H H}$ and the skilled workers and capitalist have the same income and thus $\lambda_{H}=\lambda_{K}$, then the inflow of unskilled workers will increase social welfare if the number of skilled workers exceeds that of domestic capitalists (i.e., $\mathrm{H}>\mathrm{F}$ ). As we mentioned before, most of the studies surveyed by Hamermesh (1993, p.110) found that blue collar workers are complements in production with white collar workers and the elasticities between blue and white collar workers are much higher, and in many case more than double, than the absolute value of the own demand elasticity of the white collar workers. Based on the results of the above studies we can conclude that the inflow of the unskilled workers is very likely to increase social welfare. ${ }^{19}$

\subsection{Free international mobility of both types labour}

In this subsection, it is assumed that both skilled and unskilled labour are freely mobile internationally, and examine how changes in the immigration cost on each type of labour affects social welfare. Using equations (5) and (7) for the case where $\mathrm{j}=\mathrm{L}, \mathrm{H}$, we get

$$
\begin{aligned}
& \Delta_{L H}\left(d W / d t_{L}\right)=-\rho N R_{H H}\left[\lambda_{L}-\lambda_{H} R_{H H}^{-1} R_{H L}\right], \\
& \Delta_{L H}\left(d W / d t_{H}\right)=-\rho N R_{L L}\left(\lambda_{H}-\lambda_{L} R_{L L}^{-1} R_{L H}\right),
\end{aligned}
$$

where $\Delta_{L H}=(1-\rho) N\left(R_{L L} R_{H H}-R_{H L}^{2}\right)-\rho \lambda_{H}\left(R_{L L}-R_{H L}\right)-\rho \lambda_{L}\left(R_{H H}-R_{H L}\right)$ and is positive under the assumption that an increase in the domestic supply of a factor decreases its net domestic income. This assumption is maintained throughout the analysis. The welfare effects of an increase in the immigration cost on unskilled (skilled) labour are similar to those when we have an exogenous inflow of unskilled

\footnotetext{
${ }^{19}$ These results are different from those of Kemnitz (2003), where in a model of unemployment of low skilled workers and pensions, found that immigration of low-skilled workers benefits the native population as a whole. His results however, are based on a different model and assumptions. That is, he assumes that only low-skilled workers contributes to unemployment benefits, no other taxes and income transfers exists besides unemployment benefits and pensions, and the supply of high skilled workers is fixed. Thus, the immigration of low-skilled workers does not cause any change in the supply of high-skilled workers and consequently on the income taxes and transfers.
} 
(skilled) labour. Thus, when skilled and unskilled workers are substitutes in production, then an increase in the immigration cost of unskilled workers and a decrease in the immigration cost of the skilled workers increase social welfare. When skilled and unskilled workers are complements in production, however, an increase in either immigration cost has an ambiguous effect on welfare.

Proposition 1. Assume that skilled and unskilled labour is internationally mobile.

- If skilled and unskilled labour are substitutes in production, then social welfare increases by reducing the immigration cost of skilled labour and by increasing that of unskilled labour

- If however, they are complements in production, reducing the immigration cost of the skilled labour and increasing the immigration cost of the unskilled labour may reduce social welfare. For example i) a decrease in the immigration cost of the skilled labour that causes its immigration, reduces social welfare if $\varepsilon_{L H}>-\varepsilon_{L L}$, ii) a decrease in the immigration cost of the unskilled labour that causes its immigration, increases social welfare if $\varepsilon_{H L}=-2 \varepsilon_{H H}, \lambda_{H}=\lambda_{K}$, and $H>F$.

\section{International mobility of capital.}

In this section, it is assumed that there is free international mobility of capital, the stock of foreign owned capital at home is not zero, and we examine the welfare effects of the immigration policies towards skilled and unskilled labour.

\subsection{Free international mobility of capital and unskilled labour}

First, it is assumed that capital and unskilled labour are freely internationally mobile while skilled labour is immobile. Using equations (5), (6) and (7) for the case where $\mathrm{j}=\mathrm{L}$, we obtain the welfare effects of changing the immigration cost on unskilled labour as follows:

$$
\Delta_{K L}\left(d W / d t_{L}\right)=-\rho N R_{K K}\left(\lambda_{L}+R_{K} R_{K K}^{-1} R_{K L}\right),
$$

where $\quad \Delta_{L K}=(1-\rho) N\left(R_{K K} R_{L L}-R_{L K}^{2}\right)-\rho\left(\lambda_{L} R_{K K}+R_{K} R_{K L}\right) \quad$ and $\quad$ is positive. Equation (16) shows that a decrease in the immigration cost decreases social welfare 
if unskilled labour and capital are substitutes in production. In this case, the decrease in the immigration cost increases the domestic supply of unskilled labour and this decreases social welfare directly since unskilled labour is a net fiscal beneficiary and indirectly by causing a capital outflow which causes income tax revenue to decrease. If, however, capital and unskilled labour are complements in production, this indirect effect is of opposite sign and thus the total effect on welfare is ambiguous. For the latter case, in order to get more precise results we rewrite equation (16) as

$$
\Delta_{K L}\left(d W / d t_{L}\right)=-\rho(N / L) R_{K K}\left[-\bar{R}(F+H)+H R_{H}+K R_{K}\left(\varepsilon_{K K}+\varepsilon_{K L}\right) / \varepsilon_{K K}\right],
$$

where $\varepsilon_{K K}=\left(\partial R_{K} / \partial K\right)\left(K / R_{K}\right), \varepsilon_{K L}=\left(\partial R_{K} / \partial L\right)\left(L / R_{K}\right)$ and we make used of the facts that that $L \lambda_{L}+H \lambda_{H}+F \lambda_{K}=K^{f} R_{K}, \quad \lambda_{K}=\bar{R}-R_{K}, \quad, \quad \lambda_{H}=\bar{R}-R_{H}, \mathrm{~K}=\mathrm{F}+\mathrm{K}^{\mathrm{f}}$. Equation (17) shows that when $\varepsilon_{K L}>-\varepsilon_{K K}$ and $[(F+H) / H]>\left(R_{H} / \bar{R}\right)$, then a decrease in the immigration cost of the unskilled labour that causes its immigration increases social welfare. For example, this can occur when $\varepsilon_{K L}>-\varepsilon_{K K}$, capitalists have the highest per capital income and the per capital income of skilled labour is closed to the average income. Intuitively, when capital and unskilled labour are complements in production and the elasticity is high, the inflow of unskilled labour causes a large inflow of capital. The positive effect of distributing the higher tax revenue from taxing capital income out weights the negative effect due to the inflow of the net fiscal beneficiaries' unskilled workers and the welfare of natives increases. All the studies surveyed by Hamermesh (1993) found that blue collar workers (i.e., unskilled labour) and capital are complements in production and in some cases the elasticities are quite high. Unfortunately, however, there is no report for capital demand elasticities.

\subsection{Free international mobility of capital and skilled labour.}

Next, it is assumed that capital and skilled labour are freely mobile internationally while unskilled labour is immobile. Within this framework we examine how changes in the immigration cost of the skilled workers affect social welfare. Using equations (5), (6) and (7) for the case where $\mathrm{j}=\mathrm{H}$, we get 


$$
\Delta_{H K}\left(d W / d t_{H}\right)=-\rho N R_{K K}\left(\lambda_{H}+R_{K} R_{K K}^{-1} R_{K H}\right)
$$

where $\Delta_{H K}=(1-\rho) N\left(R_{K K} R_{H H}-R_{H K}^{2}\right)-\rho\left(\lambda_{H} R_{K K}+R_{K} R_{K H}\right)$ and is positive.

Equation (18) shows that a decrease in the immigration cost of the skilled labour increases social welfare if skilled labour and capital are complements in production (i.e., $\mathrm{R}_{\mathrm{KH}}>0$ ). Intuitively, social welfare increases since the decrease in the immigration cost increases the immigration of skilled, net fiscal contributors, workers and this has a direct positive effect on social welfare. This direct effect is further enhanced by an indirect welfare improvement due to increased capital inflow and higher tax revenue from taxing capital income. In the studies surveyed by Hamermesh (1993), however, there is no conclusive evidence that capital and skilled labour are complements in production.

\section{Proposition 2.}

- When only capital and skilled labour are internationally mobile welfare increases by reducing the immigration cost on skilled labour if these two factors are complements in production.

- When only capital and unskilled labour are internationally mobile, welfare decreases (may increase) by reducing the immigration cost of unskilled labour if these two factors are substitutes (complements) in production. For example, when unskilled labour and capital are complements, a decrease in the immigration cost of the unskilled labour that causes its immigration, increases social welfare if $\varepsilon_{K L}>-\varepsilon_{K K}$ and $[(F+H) / H]>\left(R_{H} / \bar{R}\right)$.

\section{Concluding remarks}

The immigration policy of some developed countries is designed in such a way that individuals with little or no education generally have limited access to permanent migration and immigrants tend to be better educated than the rest of the population in the country of origin. It is conjectured that this is so because skilled migrants are expected to be net fiscal contributors whose migration is not expected to affect negatively the welfare of natives in the host country. The opposite is argued for the migration of unskilled workers. To examine analytically this argument, we build a model with two types of workers, skilled workers with high productivity and 
unskilled workers with low productivity. All incomes from various sources are taxed with the same rate and all tax revenue is equally distributed among all residents. Within this framework and under different scenarios concerning the international mobility of capital and the existence or not of restrictions in the migration of each type of labour, we examine how changes in the government policies which change the immigration cost and thus induce or discourage immigration affect the welfare of natives in the host country.

The analysis is carried out within a framework of a small open economy in goods and factor markets. Within this framework, we find that the welfare effect on natives from a change in the immigration cost on a type of labour depends on whether this type of labour is a net fiscal contributor or beneficiary, on the relationship in production between the two types of labour and capital and on whether the other type of labour is a net fiscal contributor or beneficiary. For example, when capital is internationally immobile, then i) a decrease in the immigration cost of the net fiscal contributor skilled labour that causes its immigration, is very likely to reduce the welfare of natives, and ii) a decrease in the immigration cost of the net fiscal beneficiary unskilled labour that causes its immigration is likely to increase the welfare of natives. Thus, the common wisdom that the inflow of skilled workers, which are net fiscal contributors, increases the welfare of natives is unlikely to be true since this inflow causes movements of capital or unskilled labour which could affect negatively the welfare of natives. Similarly, the inflow of net fiscal beneficiary unskilled labour is likely to increase social welfare.

The analysis of the paper suggests, for example, that if a country, cannot control directly the immigration of unskilled labour, as is the case with the countries members of the European Union, then the net income of the existing residents might actually fall if immigration of the net fiscal contributors' skilled workers from non European Union countries is encouraged.

\section{References}

Bauer, T. and A. Kunze, 2004. The demand for high-skilled workers and immigration policy, CEPR Discussion paper No. 4274. 
Bellettini, G. and C. B. Ceroni, 2003. Opening the borders: immigration policy, migrants' selection and human capital accumulation. Department of Economics, University of Bologna.

Berry, R. A., and Soligo, R., 1969. Some welfare aspects of international migration. Journal of Political Economy 77, 778-794.

Bucovetsky, S., 2003. Efficient migration and redistribution. Journal of Public Economics 87, 2459-2474.

Carrington, W.J. and E. Detraciaghe, 1998. How big is the Brain Drain? International Monetary Fund W.P. 98/102.

Epstein, Gil S. and Arye L. Hillman, 2003. Unemployed immigrants and voter sentiment in the welfare state. Journal of Public Economics 87, 1641-1655.

Hamermesh, S. Daniel, 1993. Labor Demand. Princeton University Press.

Huizinga, Harry, 1999. A two-region model of redistribution, migration and international trade. Journal of Public Economics 71, 335-354.

Kemnitz, Alexander, 2003, Immigration, unemployment and pensions. Scandinavian Journal of Economics 105 (1), 31-47.

Michael S. Michael, 2003. International migration, income taxes and transfers: a welfare analysis. Journal of Development Economics 72, 401-411.

Michael S. Michael and Panos Hatzipanayotou, 2001. Welfare effects of migration in societies with indirect taxes, income transfers and public good provision. Journal of Development Economics 64, 1-24.

Quibria, M. G., 1988. On generalizing the economic analysis of international migration: a note. Canadian Journal of Economics 21, 874-876. 
Razin, A., E. Sadka and P. Swagel, 2002, Tax burden and migration: a political economy theory and evidence, Journal of Public Economics 85, 167-190.

Razin, A. and E. Sadka, 1995, Resisting migration: wage rigidity and income distribution. American Economic Review, Papers and Proceedings 85, 312-316.

Razin, A. and E. Sadka, 2004. Welfare migration: Is the net fiscal burden a good measure of its economic impact on the welfare of the native-born population, CESIFO working paper No. 1273.

Wellisch, D., and Wildasin, D. E., 1996. Decentralized income redistribution and immigration. European Economic Review 40, 187-217.

Wildasin, E.D., 1994. Income redistribution and migration. Canadian Journal of Economics 27, 637-656.

Wildasin, E. D., 2004. Economic integration and the welfare state, in social union, migration and the constitution: Integration at Risk, CESifo Forum, Autumn vol. 5, no. 3, 19-26.

Wong, K.-Y., 1985. The economic analysis of international migration: a generalization. Canadian Journal of Economics 18, 357-362. 


\section{CESifo Working Paper Series}

(for full list see www.cesifo-group.de)

1752 Helge Berger and Michael Neugart, Labor Courts, Nomination Bias, and Unemployment in Germany, June 2006

1753 Chris van Klaveren, Bernard van Praag and Henriette Maassen van den Brink, A Collective Household Model of Time Allocation - a Comparison of Native Dutch and Immigrant Households in the Netherlands, June 2006

1754 Marko Koethenbuerger, Ex-Post Redistribution in a Federation: Implications for Corrective Policy, July 2006

1755 Axel Dreher, Jan-Egbert Sturm and Heinrich Ursprung, The Impact of Globalization on the Composition of Government Expenditures: Evidence from Panel Data, July 2006

1756 Richard Schmidtke, Private Provision of a Complementary Public Good, July 2006

1757 J. Atsu Amegashie, Intentions and Social Interactions, July 2006

1758 Alessandro Balestrino, Tax Avoidance, Endogenous Social Norms, and the Comparison Income Effect, July 2006

1759 Øystein Thøgersen, Intergenerational Risk Sharing by Means of Pay-as-you-go Programs - an Investigation of Alternative Mechanisms, July 2006

1760 Pascalis Raimondos-Møller and Alan D. Woodland, Steepest Ascent Tariff Reforms, July 2006

1761 Ronald MacDonald and Cezary Wojcik, Catching-up, Inflation Differentials and Credit Booms in a Heterogeneous Monetary Union: Some Implications for EMU and new EU Member States, July 2006

1762 Robert Dur, Status-Seeking in Criminal Subcultures and the Double Dividend of ZeroTolerance, July 2006

1763 Christa Hainz, Business Groups in Emerging Markets - Financial Control and Sequential Investment, July 2006

1764 Didier Laussel and Raymond Riezman, Fixed Transport Costs and International Trade, July 2006

1765 Rafael Lalive, How do Extended Benefits Affect Unemployment Duration? A Regression Discontinuity Approach, July 2006

1766 Eric Hillebrand, Gunther Schnabl and Yasemin Ulu, Japanese Foreign Exchange Intervention and the Yen/Dollar Exchange Rate: A Simultaneous Equations Approach Using Realized Volatility, July 2006 
1767 Carsten Hefeker, EMU Enlargement, Policy Uncertainty and Economic Reforms, July 2006

1768 Giovanni Facchini and Anna Maria Mayda, Individual Attitudes towards Immigrants: Welfare-State Determinants across Countries, July 2006

1769 Maarten Bosker and Harry Garretsen, Geography Rules Too! Economic Development and the Geography of Institutions, July 2006

1770 M. Hashem Pesaran and Allan Timmermann, Testing Dependence among Serially Correlated Multi-category Variables, July 2006

1771 Juergen von Hagen and Haiping Zhang, Financial Liberalization in a Small Open Economy, August 2006

1772 Alessandro Cigno, Is there a Social Security Tax Wedge?, August 2006

1773 Peter Egger, Simon Loretz, Michael Pfaffermayr and Hannes Winner, Corporate Taxation and Multinational Activity, August 2006

1774 Jeremy S.S. Edwards, Wolfgang Eggert and Alfons J. Weichenrieder, The Measurement of Firm Ownership and its Effect on Managerial Pay, August 2006

1775 Scott Alan Carson and Thomas N. Maloney, Living Standards in Black and White: Evidence from the Heights of Ohio Prison Inmates, 1829 - 1913, August 2006

1776 Richard Schmidtke, Two-Sided Markets with Pecuniary and Participation Externalities, August 2006

1777 Ben J. Heijdra and Jenny E. Ligthart, The Transitional Dynamics of Fiscal Policy in Small Open Economies, August 2006

1778 Jay Pil Choi, How Reasonable is the 'Reasonable' Royalty Rate? Damage Rules and Probabilistic Intellectual Property Rights, August 2006

1779 Ludger Woessmann, Efficiency and Equity of European Education and Training Policies, August 2006

1780 Gregory Ponthiere, Growth, Longevity and Public Policy, August 2006

1781 Laszlo Goerke, Corporate and Personal Income Tax Declarations, August 2006

1782 Florian Englmaier, Pablo Guillén, Loreto Llorente, Sander Onderstal and Rupert Sausgruber, The Chopstick Auction: A Study of the Exposure Problem in Multi-Unit Auctions, August 2006

1783 Adam S. Posen and Daniel Popov Gould, Has EMU had any Impact on the Degree of Wage Restraint?, August 2006 
1784 Paolo M. Panteghini, A Simple Explanation for the Unfavorable Tax Treatment of Investment Costs, August 2006

1785 Alan J. Auerbach, Why have Corporate Tax Revenues Declined? Another Look, August 2006

1786 Hideshi Itoh and Hodaka Morita, Formal Contracts, Relational Contracts, and the Holdup Problem, August 2006

1787 Rafael Lalive and Alejandra Cattaneo, Social Interactions and Schooling Decisions, August 2006

1788 George Kapetanios, M. Hashem Pesaran and Takashi Yamagata, Panels with Nonstationary Multifactor Error Structures, August 2006

1789 Torben M. Andersen, Increasing Longevity and Social Security Reforms, August 2006

1790 John Whalley, Recent Regional Agreements: Why so many, why so much Variance in Form, why Coming so fast, and where are they Headed?, August 2006

1791 Sebastian G. Kessing and Kai A. Konrad, Time Consistency and Bureaucratic Budget Competition, August 2006

1792 Bertil Holmlund, Qian Liu and Oskar Nordström Skans, Mind the Gap? Estimating the Effects of Postponing Higher Education, August 2006

1793 Peter Birch Sørensen, Can Capital Income Taxes Survive? And Should They?, August 2006

1794 Michael Kosfeld, Akira Okada and Arno Riedl, Institution Formation in Public Goods Games, September 2006

1795 Marcel Gérard, Reforming the Taxation of Multijurisdictional Enterprises in Europe, a Tentative Appraisal, September 2006

1796 Louis Eeckhoudt, Béatrice Rey and Harris Schlesinger, A Good Sign for Multivariate Risk Taking, September 2006

1797 Dominique M. Gross and Nicolas Schmitt, Why do Low- and High-Skill Workers Migrate? Flow Evidence from France, September 2006

1798 Dan Bernhardt, Stefan Krasa and Mattias Polborn, Political Polarization and the Electoral Effects of Media Bias, September 2006

1799 Pierre Pestieau and Motohiro Sato, Estate Taxation with Both Accidental and Planned Bequests, September 2006

1800 Øystein Foros and Hans Jarle Kind, Do Slotting Allowances Harm Retail Competition?, September 2006 
1801 Tobias Lindhe and Jan Södersten, The Equity Trap, the Cost of Capital and the Firm's Growth Path, September 2006

1802 Wolfgang Buchholz, Richard Cornes and Wolfgang Peters, Existence, Uniqueness and Some Comparative Statics for Ratio- and Lindahl Equilibria: New Wine in Old Bottles, September 2006

1803 Jan Schnellenbach, Lars P. Feld and Christoph Schaltegger, The Impact of Referendums on the Centralisation of Public Goods Provision: A Political Economy Approach, September 2006

1804 David-Jan Jansen and Jakob de Haan, Does ECB Communication Help in Predicting its Interest Rate Decisions?, September 2006

1805 Jerome L. Stein, United States Current Account Deficits: A Stochastic Optimal Control Analysis, September 2006

1806 Friedrich Schneider, Shadow Economies and Corruption all over the World: What do we really Know?, September 2006

1807 Joerg Lingens and Klaus Waelde, Pareto-Improving Unemployment Policies, September 2006

1808 Axel Dreher, Jan-Egbert Sturm and James Raymond Vreeland, Does Membership on the UN Security Council Influence IMF Decisions? Evidence from Panel Data, September 2006

1809 Prabir De, Regional Trade in Northeast Asia: Why do Trade Costs Matter?, September 2006

1810 Antonis Adam and Thomas Moutos, A Politico-Economic Analysis of Minimum Wages and Wage Subsidies, September 2006

1811 Guglielmo Maria Caporale and Christoph Hanck, Cointegration Tests of PPP: Do they also Exhibit Erratic Behaviour?, September 2006

1812 Robert S. Chirinko and Hisham Foad, Noise vs. News in Equity Returns, September 2006

1813 Oliver Huelsewig, Eric Mayer and Timo Wollmershaeuser, Bank Behavior and the Cost Channel of Monetary Transmission, September 2006

1814 Michael S. Michael, Are Migration Policies that Induce Skilled (Unskilled) Migration Beneficial (Harmful) for the Host Country?, September 2006 